\title{
Las identidades del dinero
}

Celso Sánchez Capdequí

Universidad Pública de Navarra celso.ca@teleline.es

A lo largo del trabajo se ha pretendido desvelar los momentos sociales y simbólicos que constituyen la extensa biografía del dinero. En ausencia de una racionalidad económica diferenciada, el dinero nace, de forma no deliberada, en el templo bajo la atmósfera sacrificial, comparece en la modernidad como medio técnico que representa la esperanza del individuo propietario en la bonhomía del mercado como elemento pacificador de las costumbres sociales, y arriba a nuestra posmodernidad como fin en sí mismo que, convertido en bit desmaterializado, aspira a no dejar de circular por el nuevo espacio virtual.

Palabras clave: Identidad Cultural, Religión, Dinero, Mercado, Globalización.
An attempt has been made throughout this article to explain the social and symbolic moments that comprise the extensive biography of money. In the absence of a differentiated economic rationality, money is born, unintentionally, in the temple beneath the sacrificial atmosphere, appears in modernity as a technical medium that represents the hope of the individual owning it in the geniality of the market as a pacifying element of social customs and reaches our postmodernity as an end in itself which, converted into a de-materialized bit, aspires to never cease circulating through the new virtual space.

Keywords: Cultural Identity, Religion, Money, Market, Globalization. 

Es muy frecuente en el ámbito de la sociología identificar el dinero con un mero medio técnico que contribuye a reducir la elevada complejidad de una sociedad, como la (pos)moderna, que no conoce otro intercambio que el económico y otros lenguajes que los semiológico-abstractos desprovistos del mundo-de-la-vida y, por ende, susceptibles de homologarse globalmente. Sociólogos clásicos como Marx, Weber y Simmel y contemporáneos como Parsons, Luhmann, Habermas y Giddens han fomentado esta definición del dinero al albur de una experiencia sociocultural influida por el mito del mercado pacificador ${ }^{1}$ (y de sus consecuencias fallidas) y, además, por los avatares de una sociología excesivamente ceñida a la categorización de la economía ${ }^{2}$. No en vano, en la reflexión sociológica prevalece como medio de adaptación que, operando desde el interior del subsistema económico, se encarga de obtener los recursos necesarios para salvaguardar las necesidades materiales de los individuos y, en especial, del conjunto de subsistemas. Su función adaptativa vela por el equilibrio del orden social ${ }^{3}$.

Frente al tratamiento únicamente funcional que, a instancias de la ciencia económica, la sociología realiza del dinero desconectándole de la entraña motivacional de la acción, este trabajo pretende situar el estudio del dinero en los horizontes simbólicos del mundo-de-lavida donde se forjan las formas de vivir, pensar, hablar e intercambiar. El enfoque sociohermenéutico 4 aquí empleado nos permite sospechar que por el dinero transpiran ideales sociales, que no es del todo ajeno a la racionalidad material, que en su versión más impersonal, como la contemporánea, laten ilusiones colectivas.

La presente reflexión propone la idea de que el dinero ha crecido al albur de distintos modelos de sociedad, ha integrado diferentes almas y se ha expresado en plural. No es, por naturaleza, oriundo del mercado ni su identidad es únicamente la del medio técnico. Se trata de comprobar que el dinero es una institución que, sin una conciencia racional diferenciada, nació (colateralmente) como hijo no deseado del rito sacrificial, se convirtió en la gran esperanza del hombre moderno que hizo de él el gran medio en que hacer descansar la prosperidad individual y la salud del orden social y, en nuestros días, actúa, como fin en sí mismo, desde la necesidad de garantizar su supervivencia ante una complejidad a la que pretendió combatir y que hoy dificulta su existencia. La biografía del dinero pone de relieve que nació en el templo como derivación ritual, se desarrolló en el mercado como me-

\footnotetext{
1 A. O. Hirschman, Las pasiones y los intereses, Península, Barcelona, 1999.

2 V. Zelizer, The Social Meaning of Money, Basic Books, Nueva York, 1994, pp. 7-35.

3 Ch. Deutschmann, Die Verheissung des absoluten Reichtums, Campus Verlag, Francfort del Meno, 1999 , p. 95.

${ }^{4}$ La expresión la tomo del excelente trabajo de Luis Enrique Alonso La mirada cualtitativa en sociología (Fundamentos, Madrid, 1998), en el que, entroncando con la Hermenéutica contemporánea, el autor aboga por el método comprensivo en sociología toda vez que los hechos/textos sociales a estudiar encarnan el sentido que desata los actos humanos.
} 
dio de cálculo y, en nuestros días, se toma como fin en sí mismo en la red virtual. De este modo, sus primeros pasos en las sociedades humanas transcurrieron como dinero-símbolo, creció como dinero-signo al servicio de una sociedad que creyó en el potencial del mercado para suavizar y pacificar las pasiones, y llega a nuestros días como dinero-simulacro que, desmaterializado, fluye a velocidad de la luz hasta convertirse en omnipresente.

\section{EL ORIGEN RITUAL DEL DINERO: EL TEMPLO COMO BANCO SAGRADO DE LA ANTIGUEDAD}

El nacimiento del dinero en la historia humana sólo se comprende desde la hegemonía del rito en las primeras sociedades. Sustentadas sobre niveles de diferenciación funcional muy precarios y, por lo mismo, centradas en torno al simbolismo religioso, el rito constituye la experiencia social a través del cual la sociedad regenera su estructura moral y refuerza sus señas de identidad. El simbolismo religioso impregna al conjunto de la sociedad y lo sagrado comparece como el factor aglutinante. Las categorías básicas de la representación social (espacio, tiempo, fuerza, identidad) son filiales, como señaló Durkheim ${ }^{5}$, de la experiencia religiosa (totémica). Su núcleo lo constituye el mana o numen en tanto fuerza inmanente que funde o re-liga los distintos ámbitos del mundo y anima una realidad a la que somete a permanentes procesos de cambio y transformación. La indiferenciación existente entre las esferas subjetiva (yo), intersubjetiva (sociedad) y objetiva (la naturaleza) típica del pensamiento mítico ${ }^{6}$ hegemónico en estas sociedades explica la ausencia de una conciencia económica diferenciada preocupada por las cuestiones de cálculo y beneficio económico. No es la producción económica, sino la renovación del ciclo cósmico ${ }^{7}$, la significación social central en torno a la cual el momento ritual se constituye como experiencia liminar ${ }^{8}$ por lo que tiene de proceso reconstitutivo de la communitas en que consiste la trama moral de la sociedad. La crianza de los animales sacrificiales, por mucho que sorprenda al hombre de hoy, no estaba inicialmente orientada ni a la eficacia económica ni a la alimentación, sino al sacrificio religioso. Por ello, el concepto mismo de alimentación es una «racionalización tardía del sacrificio ${ }^{9}$, efecto no-premeditado ${ }^{10}$ que se deriva de la tabuización, aislamiento y protección a que se somete al animal sagrado o tótem.

5 E. Durkheim, Las formas elementales de la vida religiosa, Akal, Madrid, 1992, pp. 8 ss.

6 J. Habermas, Teoría de la acción comunicativa II, Taurus, Madrid, 1988, p. 111.

7 S. N. Eisenstadt, «The Axial Age Breakthroughs. Their Characteristics and Origins», en The Origins and Diversity of Axial Age Civilizations, S. N. Eisenstadt (ed.), State University of New York, 1986, pp. 1-25.

8 V. Turner, El proceso ritual, Taurus, Madrid, 1990.

9 H. Kurnitzky, La estructura libidinal del dinero, Siglo XXI, México, 1978, p. 167.

10 A. Gehlen, Urmensch und Spätkultur, Aula Verlag, Wiesbaden, 1986, p. 190. 
En estas sociedades centradas en torno al discurso religioso que aúna y ordena al conjunto vario de la experiencia cultural, la vida económica es prácticamente inexistente, si por economía se entiende una actividad diferenciada con un simbolismo propio. Como el resto de las acciones sociales, depende de la organización ritual del mundo social. No existe la actividad económica despojada del simbolismo religioso. Las tímidas transacciones comerciales gozan de un nivel muy rudimentario. Carentes de regulación alguna, sólo se realizan con motivo y con ocasión de las celebraciones rituales. Sin autonomía social alguna, la (por así llamar) economía utiliza la categorización simbólica procedente de la religión. No en vano, las primeras formas de valor son inseparables del valor social y sacrificial localizado en el tótem (cerdo, buey, concha), los primeros agentes de la actividad económica son los miembros del clero que ofician los procesos rituales, los primeros espacios donde se intercambian objetos desde el punto de vista comercial son los templos, y las primeras formas de dinero nacen de los despojos y del despedazamiento del animal sacrificial y de los instrumentos utilizados en el rito, como hachas, cuchillos, trípodes, así convertidos en medios de cambio. Además, la idea de riqueza viene dada, de suyo, por la abundancia y exuberancia de la Madre Tierra y no por la participación activa del hombre en la génesis de la misma.

Por la escasa diferenciación entre las esferas de valor que presenta este modelo de sociedad, autores como Marx ${ }^{11}$, Durkheim ${ }^{12}$ y Mauss $^{13}$ subrayan que el ominabarcante valor religioso que aglutina al todo social deviene valor económico. La procedencia ritual del dinero también la intuye Max Weber al afirmar que «el papel moneda más antiguo no servía para pagar a los vivos, sino a los muertos» ${ }^{14}$. Por ello, el bien sagrado se perfila como primera forma de equivalente generalizado sin una conciencia económica diferenciada que así lo promueva de manera deliberada. Además, el mana que encierra se convierte en poder económico que realza a aquel grupo social (el clero) que organiza los ritmos de la vida social por encarnar ante la sociedad la riqueza desbordante de lo sagrado. No en vano, el carisma que envuelve al grupo hegemónico de estas sociedades, al decir de Clifford Geertz, «es un signo, no de atracción popular o de locura inventiva, sino de que se está cerca del corazón de las cosas» ${ }^{15}$.

En los enclaves culturales que se exponen a continuación (culturas mediterráneas, cultura trobiand y Grecia clásica) ${ }^{16}$ no rige el intercambio económico propio de las sociedades mo-

11 K. Marx, Elementos fundamentales para la crítica de la economía política, Siglo XXI, México, 1990, pp. 165-166.

12 E. Durkheim, Las formas elementales de la vida cotidiana, Akal, Madrid, p. 390.

13 M. Mauss, Institución y culto. Obras II, Barral Editores, Barcelona, 1971, p. 91.

14 M. Weber, Economía y sociedad, FCE, México, 1987, p. 332.

15 C. Geertz, Conocimiento local, Paidós, Barcelona, 1994, p. 148.

16 La selección de los enclaves culturales que sirven de base empírica de las primeras formas de dinero conlleva, como toda selección, cierto grado de arbitrariedad. Por ello, quedan fuera un sinfín de entornos culturales en los que habría que detener- 
dernas funcionalmente diferenciadas, en el que las unidades individuales, al decir de Habermas, valoran la interacción por los beneficios que se desprenden de ella y haciendo abstracción del otro interlocutor. Si aquí lo prioritario son los átomos individuales, en las sociedades con escasos niveles de diferenciación se intercambian símbolos que encierran significados con respecto al mundo natural (cultura mediterránea), al grupo social (cultura trobiand) y al propio hombre habitante de la ciudad (Grecia clásica).

En las culturas mediterráneas (Egipto, Mesopotamia y la Grecia preclásica) el ritmo de la sociedad gira en torno al rito sacrificial. En él tiene lugar la representación social con la que la sociedad pretende contribuir simbólicamente a la regeneración del ciclo cósmico al que se siente tan próximo. El templo es el lugar donde la sociedad materializa periódicamente su cooperación con el proceso reproductor del ciclo natural. Por ello se erige, según Walter Benjamin ${ }^{17}$, en el banco sagrado de la antigüedad (al tiempo que, según el pensador alemán, los bancos de la modernidad son templos profanos, las iglesias de la profanidad). La riqueza sagrada que allí se acumulaba era gestionada y administrada por los sacerdotes encargados de oficiar las ceremonias religiosas. Por su valía religiosa y por la majestuosidad que despertaban en los fieles, pasan a convertirse en bienes cuyo valor sobrepasa el umbral liminar del templo e invaden el tráfico social profano, ya que lo que vale religiosamente, vale a todos los niveles de la acción social (como supone Durkheim). La casta sacerdotal, al gestionar esos bienes santos, empieza a intercambiarlos por otro tipo de bienes profanos. Su aura les hace todopoderosos y valiosísimos; de esta suerte se introducen en el flujo de los intercambios profanos como elementos preñados de mana e investidos de valor numinoso. En este sentido, no le falta razón a B. Laum cuando, en su clásico Dinero sagrado, afirma que «la elección del animal sacrificial es el primer acto del pensamiento económico» ${ }^{18}$, ya que en los ritos sacrificiales de estas sociedades «las ofrendas no son tal porque sean dinero, sino que comparecen como dinero porque son ofrendas» 19 .

Es precisamente la dimensión sacramental que dimana del proceso ritual la que se desplaza al campo del comercio, instalándose como el momento inicial de la actividad económi-

\footnotetext{
se para re-validar la tesis que aquí se defiende. Sin embargo, la extensa y rica documentación bibliográfica relativa a lo que constituye la cuna de la cultura occidental (culturas mediterráneas y Grecia clásica), así como las permanentes referencias y el buen conocimiento que de la cultura trobiand existen en el ámbito de la investigación sociológica (desde la que se escribe este trabajo), pueden explicar la elección de estos reductos culturales orientada a reivindicar la tesis de validez pretendidamente universal ya formulada por Durkheim: la filiación ritual de las representaciones colectivas y, por ende, del valor económico.

17 H. Schweppenhauser, «Primeras lluminaciones. El capitalismo o cuando los bancos de la modernidad son templos profanos», El País («Temas de nuestra época»), 20 de septiembre de1990, pp. 3-5 (p. 5).

18 B. Laum, Heiliges Geld, J. B. C. Mohr, Tubingen, 1924, p. 27.

19 W. Gerloff, Geld und Gesellschaft, Vitorio Klostermann, Francfort del Meno, 1952, p. 52.
} 
ca. Es el cerdo el animal sagrado ya que, a los ojos del hombre mediterráneo, sus rápidos procesos de crecimiento y engorde simbolizan la fuerza renovadora de la naturaleza 20 . Propiamente, la autoridad que va a transmitir la confianza a los actores sociales en la valencia del cerdo como medio generalizado de intercambio es la casta sacerdotal, por lo demás, máximo representante de la creencia religiosa de fondo. En palabras de H. Kurnitzky, «así empezaron ya, sobre la base del sacrificio en especie, a acumular los mismos bienes las autoridades del templo y con ello hicieron inevitablemente que el santuario se convirtiera en el germen del comercio. Los sacerdotes eran ya en tiempos de Homero gente rica, que a veces vivían de sus rentas y debido a las elevadas ganancias económicas, podían arrendar su cargo sacerdotal. En aquel tiempo eran los templos de Oriente, con sus inmensas existencias de mercaderías, de diezmos y donaciones de ofrendas, las centrales comerciales que monopolizaban toda la circulación dineraria, y a la manera de grandes instituciones bancarias concedían préstamos y daban hipotecas»21.

El templo se convierte en un centro ritual en el que se concentra la riqueza sagrada y, por ende, la riqueza económica. Resultado de todo esto es que «los rituales sacrificiales de este tipo permitían a las autoridades del templo acumular grandes tesoros gracias al trueque de animales votivos por productos de la tierra, con lo que finalmente se tuvo el motivo y la necesidad de un comercio muy activo (sobre todo, con tierras lejanas) y los administradores del templo forzosamente se fueron animando a negocios dinerarios más audaces»22. Gracias a la riqueza sagrada acumulada para el sacrificio y a las ofrendas entregadas por los fieles, «prestigiosos templos de la antigüedad, como el de Atenea en Atenas, el de Apolo en Delfos y el de Juno Moneta en Roma funcionaban como los bancos y las tesorerías»23. Por esta razón, se ha definido al templo como «primer instituto bancario» 24 .

Por otra parte, en la cultura trobiand resalta el rito suntuario frente al rito sacrificial de la cultura mediterránea. La renovación cósmica pervive como significación social central; sin embargo, es el mago/chamán el que se ocupa de favorecerla con sus ritos mágicos. En este caso, los grupos pugnan por el reconocimiento proveniente de los otros (grupos y hombres). En el rito se libra la batalla por el reconocimiento recíproco entre las identidades culturales, es decir, el reconocimiento del pasado, de los ancestros, de los iconos y de la tradición; en definitiva, del alma de la sociedad. Aquí miden sus fuerzas grupos humanos

\footnotetext{
20 M. Gimbutas, Dioses y diosas de la vieja Europa, Ediciones Istmo, Madrid, 1991, p. 244.

21 H. Kurnitzky, op. cit., 1978, p. 53.

22 Ibid., p. 37.

23 W. H. Desmond, Magic, Myth and Money, The Free Press of Glencoe, Nueva York, 1962, p. 43.

24 B. Laum, op. cit., 1924, p. 139.
} 
entre sí, los intervinientes son culturas humanas y sus simbolismos sociales. No comparecen como interlocutores ni lo divino ni el individuo típicamente moderno, sino que son «las colectividades las que se obligan mutuamente, las que cambian y contratan; las personas que están presentes en el contrato son personas morales: clanes, tribus, familias que se enfrentan y se oponen, ya sea en grupos que se encuentran en el lugar del contrato o representados por medio de su jefes, o por ambos sistemas. Lo que intercambian no son exclusivamente bienes o riquezas, muebles o inmuebles, cosas útiles económicamente: son sobre todo gentilezas, festines, ritos, servicios militares, mujeres, niños, danzas, ferias en las que el mercado ocupa sólo uno de los momentos, y en las que la circulación de riquezas es sólo uno de los términos de un contrato mucho más general y permanente» 25 .

A estos ritos suntuarios en los que intervienen las colectividades culturales, Marcel Mauss les denomina sistemas de prestaciones totales ${ }^{26}$. En ellos el grupo anfitrión ofrece su universo simbólico, se ofrece buscando el reconocimiento del otro. No se intercambian bienes económicos, sino los significados de que se constituye el alma de cada colectivo. Lo que hay que gestionar no son cantidades económicas, sino la fibra moral de cada cultura. En la gestión de ese reconocimiento recíproco entre los grupos culturales se encuentra el principio de la paz y de la guerra entre los hombres. El don, como hecho cultual, es, en última instancia, «la racionalización de una necesidad más humana de reciprocidad cuya razón reside en otra parte: la amenaza de la guerra» 27.

Son las conchas los objetos que parecen simbolizar entre los trobiand la sacralidad de la desbordante fertilidad natural. Son cifra simbólica de fertilidad. La importancia de las conchas en la vida trobiandesa adquiere su máxima expresión en el rito suntuario. Éste se denomina Kula y, básicamente, se centra en la circulación de dos objetos cargados de valor simbólico: los largos collares de concha roja, llamados Soulava, y los brazaletes de concha blanca, llamados Mwali ${ }^{28}$. Ambos constituyen lo que los trobiandeses denominan los Vaygu'a, es decir, los objetos preciosos. Toda la vida social gira en torno a la celebración del rito Kula, que «es el objetivo principal a todos los respectos: las fechas se fijan, los preliminares se hacen, las expediciones se preparan y la organización social se determina no de cara al comercio sino de cara al Kula»29.

\footnotetext{
25 M. Mauss, Sociología y antropología, Ed.Tecnos, Madrid, 1979, p. 160. La cursiva es mía.

26 Ibid., p. 161.

27 M. Sahlins, Economía de la edad de piedra, Akal, Madrid, 1983, p. 193.

28 B. Malinowski, Los argonautas del pacífico occidental, Península, Barcelona, 1995, p. 95.

29 Ibid., p. 112.
} 
El Kula consiste en donar por parte del grupo anfitrión al grupo invitado los bienes más preciados simbólicamente y sellar, de esa manera, «una relación que se establece para toda la vida ${ }^{30}$. Bajo una atmósfera cargada de liturgias, fastos y ritos mágicos, en el Kula circula el significado del grupo y, al mismo tiempo, se compromete/se desafía al grupo donatario a gestionar con tino el regalo recibido. Al igual que en el Potlatch del noroeste americano estudiado, entre otros, por Marcel Mauss, el Kula se establece sobre los supuestos afincados en la mentalidad del hombre antiguo relativos al intercambio, al comercio, a salir de sí como principio de una existencia pacífica.

En primer lugar y fundamental, se trata de subrayar que el Kula consiste en la entrega de un regalo ceremonial al que debe corresponderse con un contrarregalo equivalente después de un cierto lapso de tiempo, ya sea unas cuantas horas, incluso minutos, ya sea un año, a veces más, el tiempo que diste entre las dos entregas. Pero no pueden intercambiarse los dos objetos mano a mano después de haber discutido su equivalencia, negociándolos y evaluándolos. Los indígenas distinguen claramente entre el carácter ritual del Kula y el Gimwali, expresión que se refiere al trueque de naturaleza meramente comercial.

Por otro lado, la equivalencia del regalo de devolución se deja al criterio del que lo hace sin coacción de ningún tipo. Quien recibe un regalo Kula se sabe comprometido a corresponder con un gesto que entraña igual o más valor. Se trata de entender que lo que está en juego es el honor, el buen nombre de la identidad grupal. Esta idea cobra expresión en el concepto de poder, que subyace a este tipo de sociedad. No en vano, poder, como bien sabía Georg Bataille, significa poder prescindir, desprenderse de lo mejor para ofrecérselo a los otros. En el extremo, «ni siquiera se trata de dar y tomar, sino de destruir, con el fin de que no parezca que se desea recibir» 31 .

Tres son los momentos que definen el proceso ritual del don. Primero, en estas culturas sobresale la obligación de dar. El jefe del grupo sólo reafirma su poder abriéndose a los otros, poniendo en circulación sus riquezas, en las que se condensa el alma del grupo. Según relata Mauss, del noble Kwaktiul y Häida que no daba Potlatch se decía que tenía la «cara podrida». Además, no es menor la obligación de recibir. El negarse a recibir un don pone en evidencia que se tiene miedo a tener que devolver y a quedar «rebajado» hasta que no se haya devuelto. Dar muestras de temor es ya quedar «rebajado», «perder el peso» de su nombre, declararse vencido de antemano. Por ello, se trata de aceptar el desafío que late en todo don recibido apoyándose en la certeza de poder devolverlo. Por último, la obligación de devolver que consiste en reconocer el gesto y el cuerpo simbólico del otro. Devolver

30 Ibid., p. 98.

31 M. Mauss, op. cit., 1979, p. 203. 
el cumplido tiene algo de imperativo ${ }^{32}$, como dice Mauss. No hacerlo supone establecer hostilidades entre los grupos porque se ha deshonrado el alma del donante y su gesto de apertura.

Sin embargo, otra cosa bien distinta, que también recuerda a la experiencia de las culturas mediterráneas, es que el símbolo suntuario de la cultura trobiand, por la propia valía que concentra y por el consenso anímico que expresa, puede desplazarse, como equivalente generalizado de valor, a las rudimentarias operaciones comerciales exentas de cualquier tipo de regulación. Sin conciencia económica que lo motive, esto es, de forma no-deliberada y colateral, las conchas, por la valía simbólica que encierran, traspasan la frontera liminar del rito y acaban interviniendo como patrón de valor en los intercambios comerciales (siempre subsidiarios en este feudo cultural). En este sentido, Géza Róheim se refiere a las formas premonetarias de dinero de la cultura trobiand en términos de «dinero sagrado»33.

Así como Marcel Mauss reconoce sin recato alguno que la moneda es un valor de contraste «cuya posesión confería a su detentador un poder que fácilmente se transformaba en poder de compra»34, Malinowski, aunque con más reservas, acaba corroborando el desplazamiento no-intencionado del valor simbólico a valor económico cuando afirma la existencia de determinadas transacciones comerciales en las que «la producción de vaygu'a (objeto precioso) es difícil determinar si se trata de un pago por servicios prestados o del trueque comercial correspondiente a esta categoría»35. Esta tesis la corrobora el especialista en las formas primitivas de dinero Paul Einzig, que, en su célebre libro sobre el tema, Primitive Money, afirma que «el propósito principal de ambos tipos de concha (soulava y mvali) es el de servir para los intercambios comerciales entre los trobiandeses y otros habitantes de las islas, y también los pagos especiales dentro de la propia comunidad trobiand»36. Asimismo, M. Godelier afirma, en relación al Kula trobiandés, que los intercambios mercantiles, los Gimwali, «son objetos de ávidos regateos y utilizan conchas como moneda» ${ }^{37}$. En definitiva, también entre los trobiand parece que las primeras formas de dinero se siguen de su condición cúltico-ritual, sin rastro alguno de una conciencia economicista y calculadora que deliberadamente las hubiera diseñado para tal fin.

32 Ibid., p. 210.

33 G. Róheim, «L'argent sacré en Mèlanesie», en Psychanalyse de l'argent (E. Borneman, ed.), Presses Universitaires de France, París, 1978, p. 217.

34 M. Mauss, Institución y culto. Obras II, Barral Editores, Barcelona, 1971, p. 91.

35 B. Malinowski, op. cit., 1995, p. 193.

36 P. Einzig, Primitive Money, Pergamon Press, Londres, 1996, p. 68.

37 M. Godelier, El enigma del don, Paidós, Barcelona, 1998, p. 237. La cursiva es mía. 
Por último, en la Grecia clásica tiene lugar la aparición de las primeras formas monetarias de dinero con acuñación estatal. Hasta entonces se tenían noticias de monedas que portaban la figura de las diosas/dioses que tutelaban los templos religiosos que las emitían. Con el advenimiento del período «socrático» de la cultura griega, el dinero monetario, junto a instituciones como la ciudad, el Estado, la democracia, el pensamiento filosófico, simboliza el gesto racionalizador, tan presente desde entonces en la cultura occidental. Las condiciones culturales que hacen posibles las formas monetarias de dinero remiten, básicamente, a la aparición de la autoconciencia humana, al surgimiento de la racionalización como elemento que diferencia al hombre del animal y de Dios. Como recuerda Karl Jaspers ${ }^{38}$, este acontecimiento histórico facilita el proceso de tímida pero ya inexorable separación del hombre respecto del entorno natural, que, desde ese momento, va a aparecer a los ojos del nuevo modelo humano como un ente a controlar y a dominar a partir del conocimiento filosófico y técnico de que se va a dotar. No conviene olvidar que, como mantenía Max Weber, el pensamiento filosófico y científico de la Grecia helenística y las profecías éticas judías constituyen las bases del gesto racionalizador que va a caracterizar a la cultura occidental desde sus primeros balbuceos.

Es en el rito cívico-político desplegado en el espacio urbano donde el hombre alcanza la mayoría de edad al tomar conocimiento de su ser autónomo (frente a Dios y a la naturaleza) y del ser de las cosas. La ruptura del hombre socrático con su ascendiente natural, el olvido de los ritos dionisíacos en los que se ensalzaba el misterio de la reproducción de la vida, en definitiva el desencuentro entre la naturaleza y la cultura que se empieza a representar públicamente en las tragedias (Edipo Rey, Antígona, etc.), dejan paso a la delimitación del espacio propiamente humano en el que va a imperar la palabra. Ésta se constituye como el principio desde el que la vida social se edifica discursivamente como orden normativo contingente sujeto a correcciones políticas. Al decir de Carlos Moya, «frente a la omnipotencia mágico-religiosa de la naturaleza en la existencia campesina, la ciudad ha constituido sus poderosas murallas, como recinto en el que se hace posible el artificio todopoderoso del Logos político; la discusión pública en la ciudad deviene razón y medida de todas las cosas, de las que son y de las que no son. Sólo es propiamente aquello cuya afirmación se impone con éxito público: lo conveniente para quien lo afirma convenciendo a los demás de su razón singular como razón común»39.

Es en la ciudad donde la naturaleza humana apalabra sus potencialidades, donde se sobrepone a la inmediatez de la vida animal y donde topa con sus límites, a diferencia de Dios, que no los tiene. Sin duda alguna, el animal político ${ }^{40}$ adquiere su autosuficiencia en

\footnotetext{
38 K. Jaspers, op. cit., 1985, pp. 20-33.

39 C. Moya, De la ciudad y de su razón, Ed. Cupsa, Madrid, 1977, p. 42.

40 Aristóteles, Política, Alianza, Madrid, 1997, p. 44.
} 
el debate político, en el que el hombre da salida a su ser moral e intelectual. La polis, la ciudad, es decir, la interacción social regulada por normas discursivamente forjadas, constituye la matriz del ser y de la identidad del hombre, y Atenas se enorgullece al saber-se el espacio cívico-político en el que el hombre toma conciencia de ello. La actividad política, en ese sentido, deviene el rito social en el que el hombre (ateniense) organiza y regula la convivencia ante el caos que habita extramuros de la ciudad.

En este decorado cultural se atisba el alba de un gesto racionalizador que define a una sociedad que aspira a organizar-se, a erigir-se en artífice y responsable de sus instituciones y de sus leyes. El ámbito de la ciudad y el rito del debate político definen los elementos que constituyen un modelo de acción que desemboca en la autoconfrontación y el autocontrol humanos. La sociedad deviene problema para sí misma y, con ella, emerge lo que Castoriadis denomina la(s) sociedad(es) autónoma(s), que, por todo lo dicho, se opone a los modelos heterónomos de sociedad en los que el hombre creía estar a disposición de dioses y tradiciones que limitaban su comportamiento a una mera repetición de un acto cosmogónico primordial.

En todo caso, no se puede hablar aún de la existencia de una racionalidad específicamente económica. No en vano, la actividad productiva a la que debía entregarse un ciudadano para poder subsistir se desaprueba en esta cultura, ya que lo que define al hombre libre era su autosuficiencia económica y, por ende, su independencia respecto a los otros. El hombre libre era aquel que al tener satisfechas todas las necesidades materiales podía dedicarse en cuerpo y alma a los problemas de la ciudad y de su gestión política. Se trataba de asuntos en los que, como apuntaba Aristóteles en Ética a Nicómaco, se requería un modelo de acción como fin en sí, la praxis. Muy al contrario, la poiesis remitía a una acción técnico-productiva (por ejemplo, la del artesano) en la que se buscaba un fin ajeno a ella misma; en concreto, el de la satisfacción de necesidades materiales. Mientras que la praxis apunta a la actualización de la naturaleza humana, la segunda, por momentos, asemeja al hombre al mundo de las bestias. Se sanciona negativamente cualquier atisbo utilitarista en la acción del hombre.

Es el oro el que sirve de soporte material a la moneda acuñada por el Estado. Su durabilidad y resistencia hacen posibles las proporciones y las equivalencias económicas, remitiendo a una cantidad de materia áurea siempre idéntica e inequívoca. Dicho de otro modo, facilita el lenguaje de la identidad y de lo equivalente en la actividad comercial, a la que, por lo mismo, regula y organiza como corresponde al escenario urbano pretendidamente desprovisto de cualquier atisbo de caos y arbitrariedad. Así lo observaba el propio Marx cuando afirma que «si evalúo todas las mercancías, por ejemplo, en bueyes, cueros, cereales, etc., tendré que medirlas, de hecho, en bueyes ideales medios, en cueros ideales medios, 
puesto que un buey difiere cualitativamente de otro, como un cereal y un cuero del otro. En cambio, el oro y la plata, en su carácter de cuerpos simples, siempre son iguales a sí mismos, e iguales cantidades de los mismos representan, por consiguiente, valores de igual magnitud ${ }^{41}$. De suerte que el oso es el símbolo de la riqueza con el que en estas sociedades se define el prestigio y se acentúa la distinción entre los ciudadanos, convirtiéndose, por ello, en «el material para las alhajas, el esplendor y el relumbrón, las necesidades dominicales, en suma, en la forma positiva de la superabundancia y la riqueza» 42 .

Por tanto, la forma monetaria en Grecia no brota de una supuesta conciencia económica que, de hecho, no existe. El dinero monetario de la polis (ateniense) bebe de las mismas fuentes axiológicas que el pensamiento filosófico, el Estado, la democracia y la ciudad. Se corresponde con el rito político de un hombre que se regodea en su mayoría de edad plasmada en el debate político. Forma parte del marco humano de convivencia, la ciudad, en el que el hombre actualiza sus potencialidades organizando y regulando por sí mismo su comportamiento en sociedad. En definitiva, a la hora de buscar explicación al surgimiento de la moneda regulada por la autoridad política convendría no olvidar, además del soporte áureo que la confiere permanencia e identidad inequívoca para la sociedad, «el desarrollo de la conciencia cívica: en la historia de las ciudades griegas la moneda prevalecerá siempre como un emblema cívico. Acuñar moneda con las armas de la ciudad constituye una orgullosa proclamación de su independencia política: se trataría de demostrar así el poderío de Atenas. La rápida extensión de la acuñación a lo largo del s. VI, fenómeno en su origen griego (aunque las primeras monedas fueron acuñadas por los reyes de Lidia), ha de ponerse, pues, en relación con el fenómeno social que significa el desarrollo de las ciudades y de los sentimientos cívicos. Una vez más constatamos que es imposible analizar estrictamente lo "económico"»"43.

\section{EI DINERO COMO EL «GRAN MEDIO» DEL MERCADO PACIFICADOR DE LA MODERNIDAD}

Tal vez nadie como A. O. Hirschman ha transmitido la fe que alentó los primeros momentos de una sociedad que creía en el mito del mercado como mecanismo social pacificador de las conductas humanas. La llustración escocesa encarnó ese gesto mercantilista en el que el hombre europeo de la modernidad incipiente creyó ver el principio de la prosperidad hu-

\footnotetext{
${ }^{41}$ K. Marx, Contribución a la crítica de la economía política, Siglo XXI, México, 1986, p. 218.

42 Ibid., p. 146.

43 M. Austin/P. Vidal-Naquet, Economía y sociedad en la Antigua Grecia, Paidós, Barcelona, 1972, p. 65.
} 
mana y de la paz entre las diferentes culturas del mundo. Como muy bien recuerda Hirschman (en el afán de explicar los orígenes de la cultura capitalista), el hombre moderno también creyó, y lo hizo con tal intensidad que, olvidándose de que era un acto de fe, lo hipostasió y lo universalizó, integrando al conjunto vario de la cultura humana bajo su autoimagen racionalizadora y secularizadora.

El proceso de encantamiento que define una modernidad tan a menudo definida como desencantada dibuja un horizonte ideal (el mercado) en el que comparece como imagen más emblemática el individuo propietario, caracterizado por una acción orientada al intercambio económico, impregnado de disciplina, cálculo y austeridad, y necesitado para su despliegue de instituciones especialmente significativas como el tiempo homogéneo, la ciudad, la técnica, el libre examen de la religión protestante y el dinero (entre otras). La propia condición de mito experimentado por la sociedad como horizonte de acción común y compartido explica que la expresión individuo propietario necesite, antes de nada, de un consenso social para que pueda emerger como ideal y para que puedan establecerse las condiciones políticas, económicas y morales que faciliten su realización en cada hombre. Por todo ello, si bien la manifestación de este mito siempre es, según Durkheim, «individual por su objeto» ${ }^{44}$, no por ello deja de ser el encantamiento de la sociedad su condición de posibilidad. El problema radica, como bien sabía el propio Durkheim, en que «es indudablemente de la sociedad de donde extrae todo lo que tiene de fuerza, pero no es a la sociedad a la que nos liga, es a nosotros mismos ${ }^{45}$. El consenso de fondo de la modernidad comparece como el destino compartido por una época que insta a todo hombre (independientemente de su posición social, confesión religiosa, cultura y género) a realizarse como individuo propietario de su vida y de sus bienes, como ciudadano de una comunidad política (el Estado) a la que se adhiere libre y autónomamente a partir de decisiones que emanan de la soberanía de su conciencia.

Se trata de un tramo de la historia occidental en el que el desplome del dominio extramundano (desde el que las sociedades tradicionales gestionaban el devenir del mundo y de los hombres) da paso a un nuevo mito (intramundano) que concita todas las esperanzas de una sociedad que amanece, la modernidad. Ésta propone un nuevo icono, el hombre, y un nuevo escenario de interacción social, el mercado. Su narrativa simbólica aglutinadora sacraliza la idea de prosperidad del género humano derivado de la simpatía que, según Adam Smith, transforma las relaciones de mercado en principio catalizador del lazo social a escala universal. En concreto, la modernidad se concibe como «sociedad civil mercantil» 46 en la que los encuentros sociales se orientan al intercambio de mercancías en

\footnotetext{
44 E. Durkheim, La división del trabajo social, Akal, Madrid, 1987, p. 205.

45 Ibid., p. 205.

46 A. Smith, La riqueza de las naciones, Alianza, Madrid, 1997, p. 55.
} 
virtud del cual los individuos, desde la más plena libertad y sin ninguna autoridad exterior a su conciencia (Iglesia Estado, etc.), dan salida a su interés económico al tiempo que, colateralmente, el orden social se robustece. El aroma productivista y comercial va a impregnar una forma de ser y hacer basada en el convencimiento de que «la acción económica está por sí misma orientada hacia el bien, que posee un carácter moral que le es especial» 47 .

Se trata de un novedoso período histórico que coincide con la descomposición de la vieja solidaridad tradicional. Nuevas estructuras sociales asoman, las jerarquías estamentales de antaño se disuelven, emerge una filosofía igualitarista que promueve el acceso de todos los individuos a altos niveles de prosperidad, la ciudad se convierte en el decorado de la relación social, el trabajo ocupa un lugar preponderante en la génesis de la identidad en detrimento de los determinismos familiares y de la adscripción religiosa, tan propios del Antiguo Régimen. Autores como Marx, Smith, Durkheim, Weber, Sombart y Veblen centran sus análisis en el período de transición traumática que se produce ante sus ojos: el paso de la sociedad tradicional a la moderna, en la que el mito del mercado pacificador ocupa un lugar destacado. Este nuevo período histórico viene apadrinado por una moral que dignifica al individuo propietario y que santifica el beneficio económico. Ambos factores confluyen en un modelo social que convierte al mercado en un nuevo principio moral de una sociedad que libera la inventiva humana de las sujeciones religiosas de antaño y que la reconduce hacia la conquista de la riqueza humana.

En este caso, el nuevo sistema que se pretende moral laica de la sociedad moderna estimula la producción individual dirigida al mercado, es decir, al beneficio. Las sujeciones morales y religiosas inherentes a una economía de subsistencia basada en la (justa) distribución de los bienes naturales se suprimen a favor de la libre voluntad individual de producir para un ente anónimo, el mercado, donde rige implacablemente la racionalidad mediosfines. El beneficio económico se constituye como el corazón del mito del mercado pacificador que carga de sentido la institución dinero como verdadero móvil de la acción individual. Su logro y obtención dibujan los perfiles del nuevo edén mundano.

En la sociedad incipientemente moderna, como afirma Luhmann, «el dinero es el triunfo de la escasez sobre la fuerza» ${ }^{48}$. Esta idea, que se constituyó como el argumento central del libro de A. O. Hirschman Las pasiones y los intereses, deriva del hecho de que la escasez ha devenido en la economía moderna escasez de dinero. Éste vive y se regenera a partir de la circulación, pasando de una mano a otra. En este sentido, el que paga recibe lo que

47 L. Dumont, Homo aequalis, Taurus, Madrid, 1982, p. 87.

48 N. Luhmann, Die Wirtschaftt der Gesellshaft, Suhrkamp, Francfort del Meno, 1989, p. 253. 
desea, el que no paga ha de limitarse a observar. Sin embargo, el componente pacificador del dinero se basa en que éste «circula y distribuye la escasez de un momento a otro entre distintos portadores ${ }^{49}$. El que paga recibe lo que desea, pero aumenta su escasez y transmite la capacidad de pago a otras manos. Así se hace perceptible lo que se denomina el doble círculo inherente a la circulación económica. Según Luhmann, «los pagos son algo doble: generación de la capacidad de pago para el receptor y generación de la incapacidad de pago para el pagador ${ }^{50}$. De esta forma, el dinero invisibiliza la paradoja tener/no-tener, «sustituyendo la presencia actual por la posibilidad de ganancias ulteriores. Diferenciando de esta forma en el tiempo el problema (la escasez) y su solución (la abundancia), la paradoja se temporaliza, la escasez queda constantemente diferida» ${ }^{51}$.

Puede decirse de las sociedades modernas que se aferran al mito del mercado como mecanismo de integración de unos individuos de cuya acción (y sólo de ésta) brota el lazo social sin depender de instancias exteriores a ellos. El eje de este modelo social lo constituye la idea del hombre universal representado en cada individuo y en cada cultura, que se enseñorea de su primitivismo de antaño interactuando con los otros desde la autocontención, el temple y la mesura. No oculta el sustrato pasional que desata sus actos, el fondo emocional que tira de él. Sin embargo, su mayoría de edad viene dada por una idea de sociedad que se piensa desde los individuos autónomos que aspiran al interés económico pero no a cualquier precio. Aquí radica el componente civilizador y educador de la pasión comercial. El elemento regulador de su conducta no le viene dado por imposiciones exteriores (la Iglesia o por pacto con un soberano político, como se recoge en el Leviatán de Hobbes), sino por la simpatía de la que habla A. Smith, es decir, por la mutua comprensión y aprobación que los hombres realizan de los motivos de los otros hombres que, llevados inicialmente por el interés económico, sintonizan, más allá de éste, en una misma pasión, dando curso a actos que cristalizan en estructuras de moralidad en las que se reconocen recíprocamente. Por ello, lejos de derivar en una sociedad en permanente estado de guerra, la pasión (comercial) puede dar pábulo a una sociedad civilizada (A. Smith), a «una versión más amable que la del Leviatán de Hobbes „52. En concreto, tras el mercado se adivina en el hombre moderno «la aspiración a encontrar un medio de desdramatizar el cara a cara de los individuos, de desapasionar sus relaciones, de desactivar la violencia virtual de las relaciones de fuerza. El mercado pretende responder a estas exigencias. Intenta construir el poder de una mano invisible, neutra por naturaleza en tanto no personalizada»53.

\footnotetext{
49 Ibid., p. 253.

50 N. Luhmann, Ökologischer Kommunikation, Westdeutscher, Opladen, 1990, p. 110.

51 A. J. Haesler, Sociologie de l'argent et postmodernité, Libraire Droz, Ginebra, 1995, p. 123.

52 N. Dodd, The Sociology of Money, Polity Press, Cambridge (Ingl.), 1994, p. 119.

53 P. Rosenvallon, Le capitalisme utopique, V, Editions du Seuil, París, 1999.
} 
La sociedad de los individuos (N. Elias) basada en el mercado se concibe como autoinstituida $^{54}$ desde el momento en que la actividad mercantil libremente gestionada por los individuos genera, colateralmente, el cemento invisible que les vincula moralmente más allá de su interés económico inicial. Siendo éste el acicate de sus encuentros, su efecto salutífero desemboca en redes de solidaridad que regulan el tráfico social. El orden social es prolongación y cristalización (no deliberada) de la interacción. En este sentido, los pensadores liberales que reflexionaron sobre el mercado coincidiendo con el advenimiento de la modernidad no se acercan a él desde el prisma del individuo depredador que no encuentra término a su sed de dinero. Antes bien, ven en él un principio político que, en cuanto tal, se pretende como «el arte de combinar pasiones. Su objetivo es el de armonizar las pasiones de tal forma que la sociedad pueda funcionar. La aritmética de las pasiones se convierte a partir del siglo XVII en el modo de suministrar un fundamento sólido al ideal del bien común del pensamiento escolástico. No en vano, las pasiones son el material sobre el que trabajan los políticos» 55 . Esta tesis es la que subraya A. O. Hirschman al recordar, en relación a las pasiones, que, imposibles de contener exteriormente vía poder político, o interiormente vía concienciación religiosa, la modernidad libera de entre ellas la pasión económica orientada al interés en la medida en que obliga a la neutralización recíproca de las unidades individuales que se acercan al mercado. Es más, su virtualidad descansa en que en ella se combinan armoniosamente las pasiones y la razón: a pesar de la sed de enriquecimiento económico, éste exige pulir y refinar el gesto humano, sublimando y depurando de irracionalidad sus modos de interacción con el otro.

Se constata, por tanto, que al hablar del mercado plasmado en el encuentro azaroso de los individuos, el trasfondo al que apunta es el orden de la sociedad. De hecho, una de sus figuras más destacadas, Adam Smith, «piensa la economía como fundamento de la sociedad y el mercado como catalizador del orden social» ${ }^{56}$. De este modo, el mercado se convierte en auténtica «religión civil» 57 en la que, azarosamente, se armonizan las virtudes públicas y el interés privado. Una de las razones que pueden a ayudar a explicar esta armonización descansa en la idea de simpatía que defiende A. Smith a la hora de explicitar las virtualidades de la interacción mercantil. Según el fundador de la ciencia económica, la simpatía «puede hoy utilizarse sin mucha equivocación para denotar nuestra compañía en el sentimiento ante cualquier pasión» 58 . Si bien el mercado atrae a los individuos entre sí,

\footnotetext{
54 Ibid., p. 11.

55 Ibid., p. 14.

56 Ibid., p. 70.

57 A. J. Haesler, op cit., 1995, p. 291.

58 A. Smith, La teoría de los sentimientos morales, Alianza, Madrid, 1997, p. 52.
} 
en él brotan estructuras normativas derivadas de las afinidades anímicas de los individuos. La simpatía alude al efecto no deseado en el que se positiviza la competitividad económica a partir del surgimiento de pautas de interacción que, basadas en unas pasiones comunes, facilitan el reconocimiento recíproco de sus miembros. La contribución socializadora de la simpatía obedece a la necesidad de todo hombre de compartir sus sentimientos con los demás, de ser reconocido por el otro en el fondo de su ser. En palabras de Adam Smith, "cualquiera que sea la causa de la simpatía, cualquiera que sea la manera en que sea generada, nada nos agrada más que comprobar que otras personas sienten las mismas emociones que laten en nuestro corazón y nada nos disgusta más que observar lo contrario» 59 .

En el escenario de esta sociedad civil mercantil, la interacción económica no se despliega a partir de relaciones de dependencia entre los individuos que ponen en situación de necesidad a unos respecto a otros. Sobre tales desniveles es imposible edificar un modelo de sociedad exento de violencia y desigualdad. El mercado carece de los nexos sociales premodernos basados en el parentesco y el clientelismo. Se alza sobre la idea de simpatía natural que remite a un «mecanismo procesual sin contenidos emocionales o morales intrínsecos. La gente modera su comportamiento para atraer la simpatía de los otros continuando la interacción si los otros "simpatizan" con su idea y su conducta» 60 .

La simpatía no apunta a un contenido concreto que, a priori, pudiera comprometer a los individuos. Los compromisos, de darse, siempre resultan de la acción; en este caso, del reconocimiento que los individuos efectúan del quehacer del otro y de los motivos subyacentes. Si el encuentro humano es inicialmente comercial, la simpatía hace que algo común crezca entre los individuos que, celosos de sus propios intereses económicos, se van viendo comprometidos en, e identificados con, entramados nómicos derivados de su propia intervención social. La aprobación recíproca entre hombres que deciden libremente sus actos desemboca en horizontes de acción compartidos que apuntan a ley, hábito, norma, es decir, a nexos de moralidad en su hacer común que se inicia en la búsqueda del interés económico. La simpatía, por tanto, «establece la base moral de la sociedad comercial en la asociación de individuos privados que se plasma en un espacio social no construido por constreñimientos institucionales. El control mutuo de la conducta que resulta a partir de un juego completo de interacciones y mecanismos reflexivos, es la fuente y el prototipo de la conducta moral. Por ello, la simpatía modera ideas y comportamientos, robusteciendo los sentimientos de comprensión mutua en un espíritu esencialmente democrático. Con ello se

59 Ibid., p. 57.

60 A. Silver, «Friendship in Commercial Society: Eigtheenth-Century Social Theory and Modern Sociology», American Journal of Sociology, n. ${ }^{\circ}$ 95, 1990, p. 1482. 
disuelven los lazos exclusivistas definidos por la costumbre, el grupo corporativo, la posición y la jerarquía»61.

Los efectos fecundos de la simpatía, que prenden en los encuentros sociales en el mercado, también obedecen a que la pasión económica no es en absoluto tan voluble y efímera como el resto de las pasiones. La llustración escocesa la promueve porque el amor hacia el dinero conlleva necesariamente constancia y sistematicidad en la conducta. $\mathrm{O}$, lo que es lo mismo, la repetición de encuentros entre los (mismos) agentes movidos inicialmente por una fidelidad absoluta al apetito económico genera las condiciones sociales para el conocimiento mutuo, la complicidad, la confianza recíproca; en definitiva, la simpatía. Y es que la pasión económica implica reiteración y constancia; más aún, tiempo, plan y sistema para consumarse. El enriquecimiento vía cálculo (que es lo que distingue, según Weber, al capitalismo moderno de cualquier otra versión de capitalismo) obliga al individuo a introducir elementos de enorme previsibilidad en su comportamiento. Por tanto, la simpatía labra su obra en el intercambio mercantil ya que, por oposición a otras pasiones, el interés económico se convierte en el principio rector de una acción basada en la repetición y la reincidencia, no sujeta a modificaciones espontáneas e imprevisibles. La obtención del interés es cosa de tiempo, esto es, exige constancia y denuedo, método y plan. Ignora, por tanto, la improvisación, la sorpresa y lo repentino. En este sentido, la pasión económica acaba provocando pautas de interacción entre agentes que se re-conocen en su pasión compartida, duradera y constante y que se sirven de ellas para establecer un mutuo conocimiento, así como redes de solidaridad, cooperación y confianza. Por tanto, «existe una ventaja para los demás en esta persecución individual del interés, puesto que su actuación se hace consecuentemente transparente y predecible, casi tanto como la de una persona totalmente virtuosa» 62 .

En este sentido, el medio dinero brilla con luz propia en la aurora de la modernidad. A los ojos del nuevo (modelo de) hombre emancipado, su concurso contribuye a la domesticación definitiva de la irracionalidad y al triunfo de la civilización. Según Norbert Elias, el dinero encarna la autocontención pasional del hombre moderno que, forzado a actuar desde el cálculo, aleja la violencia y la fuerza de su comportamiento. Por ello, «además de ser la prefiguración del mal —como concibe aún la tradición cristiana- el dinero es un mal necesario, un receptáculo que canaliza las pasiones destructivas de las relaciones humanas»63. En él cuajan buena parte de las esperanzas de una sociedad que parece distanciarse de la barbarie de antaño a partir de una idea de mercado universal que fuerza a los individuos y

\footnotetext{
61 Ibid., p. 1484.

62 A. O. Hirschman, op. cit., 1999, p. 72

63 J. A. Haesler, op. cit., 1995, p. 215. Las cursivas son mías.
} 
a las culturas a interactuar gestionando las pasiones y sublimando las emociones. El suelo firme de la nueva sociedad lo constituye, por tanto, el interés individual que provoca encuentros entre los hombres despojados de sus impurezas pulsionales y de sus hábitos heredados. Como sostiene Sigmund Freud, la cultura derrota a la naturaleza y el orden a la ambivalencia. La violencia entre los hombres queda desterrada. De hecho, la competitividad, que se da con especial énfasis en la economía moderna, sería, según Veblen, una versión canalizada y depurada emocionalmente de las luchas y combates crueles y encarnizados que eran moneda común en períodos anteriores de la historia.

En efecto, como bien sabe Luhmann, en un modelo social aglutinado por una economía abierta al interés económico, la escasez se traduce en escasez de dinero, la penuria material en penuria de dinero. Quien carece de él no puede operar en el mercado, limitándose a observar cómo actúan los demás. Por el contrario, aquel que lo posee tiene libertad de movimientos y posibilidad de elegir. En todo caso, su presencia tiende a civilizar las pasiones. Con él, la estructura de suma cero del mecanismo tradicional de cambio se transforma en un juego de suma positiva. De modo que bajo la forma dinero la riqueza no perece, deviene, no se agota, circula, socializándose. Dicho de otro modo, el dinero hace posible en su circulación permanente que el pago y el no-pago se simultaneen en una misma operación económica. A esto se refiere Luhmann cuando habla del doble círculo inherente a la actividad económica. El dinero no se diluye en la operación económica, tan sólo cambia de manos, de modo que la posibilidad de beneficio en el juego de los intercambios se abre para cualquier miembro de la sociedad.

El derecho a la prosperidad individual se democratiza con ayuda del dinero. Es precisamente la idea de un futuro mejor lo que parece impedir el estallido de la violencia humana en la sociedad. La nueva imagen del hombre burgués próspero y reconocido socialmente se democratiza y parece encontrarse al alcance de cualquier miembro de la sociedad. Las pasiones se contienen porque el dinero neutraliza los efectos disgregadores inherentes a la escasez, es decir, abre la puerta a un juego de suma positivo. Como recuerda Simmel, en el intercambio no-monetario de las sociedades tradicionales, sólo una de las partes estaba interesada en despojarse de un objeto o en obtenerlo. En los intercambios mercantiles son las dos partes las interesadas ya que ambas se benefician, una satisfaciendo una necesidad, otra acaparando riqueza económica, es decir, dinero. En palabras del propio Simmel, «el dinero puede hacer, al menos en principio, que todo intercambio resulte beneficioso para ambas partes; la una, que recibe el objeto natural, lo hace porque lo necesita en ese momento; la otra, que recibe el dinero, también lo necesita ahora porque lo necesita en cualquier momento» 64 .

64 G. Simmel, Filosofía del dinero, Instituto de Estudios Políticos, Madrid, 1977, p. 349. Sobre este y otros aspectos del pensamiento acerca del dinero en la modernidad, consultar mis trabajos: Las máscaras del dinero (Anthropos, Barcelona, 2005, 
En este sentido, la vida moderna apunta a esa circunstancia histórica en la que el impulso mítico del mercado pacificador desemboca en la deificación de la racionalidad formal que coincide con el oscurecimiento de otras instancias de valor que dificultan el funcionamiento mecánico del cálculo. Se trata de un horizonte de valor que es enormemente dependiente de la neutralización del matiz, de la cualidad, de la expresividad; en definitiva, de la diferencia. En otras palabras, la racionalidad material con arreglo a valores se esteriliza por la capacidad arrolladora de una mentalidad burguesa que se reconoce en ademanes como el plan, el método, la previsión, la austeridad, que dibuja una trama de relaciones sociales en las que reina la objetividad y la impersonalidad, que organiza el mundo desde el semiologismo abstracto y preciso del número. El horizonte de acción moderno simplifica y reduce la complejidad del mundo pavimentando el terreno para la edificación de un orden social que, como afirma Bauman, se sabe artificial, se sabe, según Nietzsche, humano, demasiado humano. No en vano, el individuo propietario actúa movido por una pasión que es incompatible con cualquier otra, ya que, como recuerda Hirschman, mientras las demás son efímeras, inconsistentes y esporádicas, la búsqueda del dinero exige plan, proyecto y previsión a largo plazo, es decir, se sustancia en un comportamiento sujeto a método, basado en la constancia y necesitado de rigor.

Tal vez el eco de la sentencia nietzscheana Dios ha muerto retumba con demasiada fuerza en la conciencia del hombre moderno, de modo que éste, sabedor de su soledad y de su responsabilidad, acentúa titánicamente hasta la extenuación sus capacidades de control y de dominación pretendiendo emular (sin llegar a lograrlo) a las del Todopoderoso (ya definitivamente ausente). De puro verse solo, tensa sus fuerzas y pule su pericia para lograr una estabilidad y una previsión a sus actos que recuerden a las de los tiempos recién concluidos aderezados de fe religiosa. En este caldo de cultivo florece el medio técnico dinero. Su omnipresencia y protagonismo social hacen pie en un horizonte de acción confundido con infinitud objetiva y homogénea susceptible de ser tratado con la precisión que aporta el cálculo dinerario. Como bien sabían Adorno y Horkheimer, la llustración pivota en torno al número en una circunstancia histórica dada a la generalidad abstracta de la cantidad. La hegemonía de una racionalidad formal ocupada únicamente en cuestiones de beneficio económico supone, al mismo tiempo, la quiebra de la racionalidad material que atiende en su funcionamiento al suministro de valores no-económicos. De esta manera, la modernidad garantiza lo que, según Bauman, la define: la solidez y la consistencia, paradójicamente basadas en la fluidez de un líquido, el dinero.

Por todo ello, el propio Luhmann habla del simbolismo diabólico del dinero, ya que en él conviven las fuerzas simbólicas que unen lo separado y las fuerzas diabólicas que separan 
lo unido. Si, por un lado, el dinero une pagar y no-pagar, también separa a la mercancía de cualquier otra simbolización no-económica. El lenguaje preciso, general y descontextualizado del dinero reduce la complejidad de la realidad y, con ello, los matices, las cualidades y otras formas de valorar. Su simbolismo es incompatible con cualquier otro (el religioso, el moral, el estético, etc.). En palabras de Luhmann, «el dinero es un medio simbólico en la medida en que, como medio generalizado, mantiene unidos los valores positivos y negativos. Y es un medio diabólico en la medida en que neutraliza todos los demás valores en el plano del código y desplaza al estatus inferior las razones para pagar y no-pagar»65. Lo diabólico del dinero se constata en su naturaleza, que, como el Mefistófeles del Fausto de Goethe, el espíritu que siempre niega, también niega la posibilidad de interferir con razones de naturaleza extraeconómica (política, ética, religiosa) en el devenir de las operaciones económicas. En sus compras y en sus ventas los actores suspenden sus relaciones con otros aspectos que forman parte de su existencia, empobreciéndola. El dinero desintegra porque reduce al individuo a mera racionalidad calculatoria que le desconecta de sí mismo, de los otros, de la naturaleza y de otros simbolismos inherentes a la condición humana (como los relativos a la experiencia estética, religiosa, política, etc.). Lo que el simbolismo de Dios une (el Bien, la Belleza y la Verdad) en las sociedades tradicionales, la diabólica del dinero lo separa en una modernidad que se despliega generando diferencias sobre diferencias. No conviene olvidar que, como recuerda Luhmann, el demonio representa en la cosmología religiosa la función que introduce la diferencia moral en el mundo. En este sentido, como dice Josetxo Beriain, en la lógica de las cosas está que el dinero, además de mediar entre los hombres, mediatiza ${ }^{66}$ sus relaciones, no dejando en ellas otros efectos que indiferencia, anonimato y conflicto.

En este sentido, como bien recuerda Hans Joas ${ }^{67}$, el ideal de una sociedad pacificada y civilizada no se ha realizado. Acontecimientos de una violencia extrema han tenido lugar en la historia reciente de la humanidad. Lo más cruel y salvaje del hombre ha brotado con una virulencia inusitada. Además de otras muchas razones de naturaleza histórica, política y religiosa, la economía también tiene su responsabilidad al difundir universalmente «la promesa de riqueza absoluta, el sueño del individuo de disponer de la totalidad de posibilidades humanas, que es inherente a la forma de poder del dinero» 68 . Este sueño, lejos de favorecer la armonía entre los individuos y las culturas, la ha debilitado porque la ambición humana que se esconde en el dinero no tiene límites. De este modo, el poder del dinero se ha

\footnotetext{
65 N. Luhmann, op. cit., 1989, p. 245.

66 J. Beriain, La integración de las sociedades modernas, Anthropos, Barcelona, 1996, pp. 241 ss.

67 H. Joas, «Die Modernität des Krieges», en Leviathan, 24 Jahrgang, Heft 1, 1996, pp. 13-24.

68 Ch. Deutschmann, Die Verheissung des absoluten Reichtums, Campus Verlag, Francfort del Meno, 1999, p. 179.
} 
revelado como altamente nocivo en el marco de un mito social que alienta la acción encaminada a la prosperidad. Encarna una pasión (económica) que acaba privatizando las conciencias, separando y enfrentando a los hombres y oscureciendo el orden normativo de una sociedad que ha debilitado el espacio público. Por ello, hoy más que nunca es necesario el retorno crítico de la propia sociedad a los supuestos imaginarios que han hecho de ella un proyecto social truncado. Sólo rememorando la condición social, histórica y contingente de toda mitificación humana puede reconducirse un curso de acción social abocado a la catástrofe. En resumen, llega la hora de «despertar del sueño dogmático, del narcotizante de la riqueza absoluta» 69 .

\section{EL DINERO COVERTIDO EN SU «PROPIO FIN» EN LA POSMODERNIDAD LÍQUIDA}

Si algo caracteriza a la sociedad posmoderna es el consumo. Éste se impone como el gesto que define una forma de vida que, como dice Baudrillard ${ }^{70}$, encanta la forma pero con la particularidad de que en este encantamiento las formas y los signos dejan de representar algo exterior a ellos. El consumo consiste en el consumo de signos que ya no remiten a los objetos del mundo empírico, que ya no se refieren a nada sólido. Se trata de simulacros que, más que significar, discriminan estilos de vida, que nacen para ser consumidos en el juego de inclusión/exclusión social y que gozan de una vida muy breve, como la de todo aquello que es natural del mundo de la industria cultural. Encajan con el carácter líquido que define la sensibilidad de este período histórico-social en el que destacan los valores quebradizos, precarios, volátiles y hasta nuevo aviso, la novedad permanente, la sobrecarga propagandística, el diseño, la estética y las identidades como proyectos a reconstruir de continuo.

La consolidación de ese sustrato cultural desata una acción social que ya no es gestionada por un yo autosuficiente que interviene en el mundo para eliminar de él todo atisbo de sorpresa y que se reconoce en valores característicos de la modernidad, como son la abnegación y la disciplina en el trabajo, el ahorro y la austeridad en el gasto, la soledad y la desconfianza en las relaciones sociales, la llamada y la vocación como acicates para la acción. El consumo se acredita como rasgo de un modelo de sociedad en el que los individuos liberan su potencial onírico para autoexpresarse de múltiples formas, siempre transitorias, fugaces y reversibles. Sin duda alguna, se trata de una sociedad en la que la estética sustituye a la ética como elemento de integración social, ya que los individuos socializan sus vidas en el consumo, interactuando en un escenario que promueve experiencias intensas, la

69 Ibid., p. 172.

70 J. Baudrillard, Le paroxyste indifferent, Editions Grasset, París, 1997, p. 15. 
liberación de lo onírico, el trastocamiento de las identidades, etc. Y, sobre todo, la reproducción de las estructuras sociales de la desigualdad.

Sobre este decorado social saturado de riqueza, prosperidad y bienestar (de reparto siempre injusto) el dinero vive una experiencia inédita. Si su origen estuvo ligado al simbolismo de la abundancia de riqueza cósmica y posteriormente, en la modernidad, al mito de la abundancia económica del individuo (y de la sociedad), en la posmodernidad su circulación apunta a la abundancia de sí mismo. Dicho de otro modo, es el dinero el que quiere abundar. Frente al dinero de la abundancia, la sociedad posmoderna promueve la abundancia de dinero, su flujo y circulación permanente. Idea ésta que cuadra con una cultura del espectáculo que sólo puede innovar y sorprender de continuo porque el dinero, ya aligerado de peso y de materia, se ofrece y se brinda (en forma de créditos públicos y privados) como en ningún otro período de la historia. El dinero no mira más allá del sistema económico en el que habita. Se acabaron las sospechas en relación al dinero pues ya no tiene nada que ocultar: es su propio fin y funciona desatendiendo sus entornos éticos, religiosos, políticos y medioambientales. En aras de su propia circulación, está movido por una a-moralidad absoluta, ciego ante los efectos que sus decisiones pueden acarrear en los entornos del entramado económico de la sociedad.

Como bien recuerda Simmel, la circulación permanente de dinero y la concomitante proliferación de transacciones económicas a lo largo y ancho del mundo sólo son posibles con una condición: su «espiritualización progresiva» 71 , tendencia que él detectó en su tiempo en el dinero-papel y que, ya ante nosotros, se acentúa en el dinero-plástico y en el dinero como ente digitalizado. Su omnipresencia sólo es posible mutando de forma y de escenario, esto es, convirtiéndose en bit que circula a velocidad de la luz por el nuevo espacio de flujos, haciendo posible operaciones económicas que trascienden los límites espacio-temporales. Con el dinero digital «pasamos a la circulación pura, que no sólo carece de referente real, sino que también es más higiénicamente pura, libre de todo germen» ${ }^{72}$. De hecho, «los bits son dinero puro» ${ }^{73}$. Esta nueva forma de expresión del dinero es congruente con una cultura audiovisual que empieza a enterrar en la memoria humana la cultura escrita ${ }^{74}$ a cuyo cargo prevalecieron el dinero amonedado y el papel-moneda. Con este innovador ropaje del dinero se consuma algo que empieza a vislumbrarse en los pe-

71 G. Simmel, Filosofía del dinero, Instituto de Estudios Políticos, Madrid, 1977, p. 216.

72 A. J. Haesler, op. cit., 1995, p. 216.

73 B. Vief, «Digitales Geld», en Digitales Sein. Asthetik der elektronischen Medien (F. Rötzer, ed.), Suhrkamp, Francfort del Meno, 1991, p. 117.

74 Ibid., p. 117. 
ríodos histórico-sociales precedentes: «la historia de la monetarización es también la historia de las tentativas de hacer desaparecer el dinero material» 75 .

En este nuevo decorado virtual el dinero es una ficción, un simulacro, pura información. Como dice Castells, mera expectativa. En definitiva, nada, pero es nada como forma de ser, para no dejar de ser. Más aún, para no dejar de ser/estar en cualquier parte del planeta en tiempo real. Despojado de cuerpo y de materia, transita por el espacio virtual a velocidad de la luz. No en vano, en la sociedad posmoderna «la categoría económica del valor es absorbida por el valor de la información» 76 , ya que la rentabilidad de las acciones económicas va a depender de la capacidad de los agentes para generar, procesar y aplicar con eficacia esa información. Si en sociedades precedentes el dinero estaba a disposición de la vida celebrada en los ritos sacrificiales y a disposición del individuo favoreciendo su prosperidad, en la posmodernidad todo está a su disposición. Todo lo dispone para que su ciculación no se coagule y no cristalice, para que, en realidad, no pase nada en un recinto social que da pábulo al intercambio de simulacros carentes de sentido y valor más allá del mero intercambio. De hecho, se paga para seguir pagando, para que no se detenga la circulación del dinero. Éste se libera de tutelas religiosas (Iglesia) y políticas (Estado) introduciendo un ritmo enloquecedor en una vida social que celebra la mutación de cosas, relaciones, valores e identidades por la mutación misma.

En esta atmósfera de consumo masivo, asediada por la novedad y por la urgencia del individuo por forjar una identidad en permanente reconstrucción, el dinero lucha por adaptarse a la nueva circunstancia epocal. La crisis de la modernidad supone la crisis de los referentes como el oro (el hombre productor, las necesidades humanas, la evolución histórica), y el dinero, si quiere pervivir, debe modificar su orientación, su disposición material y sus ámbitos de circulación. Para todo ello, debe pensarse a sí mismo como fin en sí y para sí mismo; en alguna medida, debe reinventarse en una época de la historia en la que la autoexpresión ha sustituido al control, el gasto al ahorro y el glamour a la austeridad. El desplome de lo sólido y la emergencia de lo líquido le obligan a autorreflexionar sobre su supervivencia y su adaptación a este nuevo medio social. La desaparición de su soporte material anuncia algo más: la des-nacionalización de un dinero digitalizado que ya no dispone de cuerpo físico sobre el que reseñar identidades políticas.

Sobre este horizonte cultural crece la noción del dinamismo perpetuo e infatigable del dinero. Su supervivencia pasa por circular, fluir y transitar sin fin. El estancamiento es su muerte. Por ello, su experiencia actual está en sintonía con el imaginario posmoderno que, en el

75 A. J. Haesler, op. cit., 1995, p. 215.

76 B. Vief, op. cit., 1991 , p. 117. 
mundo de la ensoñación y la fantasmagoría que ha desatado, privilegia nociones como las de sorpresa, novedad, fascinación, fetichismo, impacto, etc. Ajeno a las ideas de utilidad y necesidad (desprovistas de soporte referencial), su circulación bebe del nutriente simbólico que hace posible y que naturaliza el pago/gasto compulsivo. Circula alimentando la novedad, regenerando la oferta, estimulando la(s) necesidad(es) en el individuo y, por ende, facilitando los pagos. El rápido envejecimiento de las mercancías y la celeridad con la que su lugar es ocupado por otras sintonizan con la hiperactividad en el gasto y en la circulación dineraria, facilitada desde el seno de la actividad económica a través de los bancos. Éstos no cejan en su empeño de inyectar sumas y sumas de dinero favorecedoras del consumo bajo la forma de préstamos/créditos (públicos y privados). De hecho, el dinero sólo puede circular con pagos, sólo puede reproducirse gastando.

Por ello, en este nuevo modelo de sociedad «queda un resto de riesgo, un riesgo central, a saber, el riesgo de no reconstitución de pago»77. En buena parte, el pago es promovido por el imperio de la novedad sin fin como significación social posmoderna desde la que se generan necesidades de continuo, se incentiva el gasto y se normaliza el endeudamiento como parte integrante del estilo de vida del hombre contemporáneo. Por ello, dinero y novedad se necesitan mutuamente. Sin la capacidad proteica y la elasticidad del primero para transformarse en ininterrumpidos acicates para el consumo, la novedad se detendría. Sin la hegemonía (imaginaria) de ésta, consistente en estimular de continuo la atención del consumidor, no se gastaría dinero desaforadamente y se paralizaría su proceso de reproducción y de circulación. Para que haya novedad, el dinero tiene que ofrecerse a sí mismo para así regenerar la oferta e invertir (en estímulos para el gasto/pago), pero para que el dinero se reproduzca debe imperar la novedad como significación social promotora de pagos.

En nuestras sociedades la economía asume la necesidad de dinero para generar dinero, es decir, de prestar dinero para hacerlo circular, de adelantar el tiempo futuro en el presente, convirtiendo a éste en un horizonte de acción plagado de riesgos y contingencias. Desplomados ya los referentes, la economía entra ya en un período en el que se convierte en fin en sí y para sí, desatendiendo los requerimientos de su entorno. Lo importante es que el flujo de dinero no se detenga, que no se interrumpa la capacidad de pago de los actores. Más aún, su vida (su circulación) depende del incentivo al gasto tan propio de nuestra época. La secuencia que está a la base de este razonamiento es la siguiente: para reproducirse, el dinero promueve el gasto (bajo la égida de la novedad) y, para ello, naturaliza el endeudamiento. Con referencia a éste, el subsistema económico produce una diferenciación interna en forma de un mercado de dinero en el que, en el caso del crédito privado, sólo el propio dinero establece las condiciones sin intromisión de lo político.

77 N. Luhmann, Soziologie des Risikos, De Gruyter, Berlín, 1991, p. 189. 
La economía actual entiende el pago desde el endeudamiento, paso necesario para la revitalización del flujo de dinero, ya que donde no hay posibilidad de pago/consumo el protagonismo ha de recaer en "los bancos, que conceden un crédito, "compran" incapacidad de pago y lo hacen en referencia a la adquisición de capacidad de pago (intereses)»78. Esto provoca que la economía se temporalice, es decir, que desatienda la cuestión del aprovisionamiento material para satisfacer las necesidades inmediatas; por tanto, que «en lugar del aseguramiento en el presente de la propiedad aparezca la preocupación por el valor futuro de la propiedad» 79 . De este modo, una cantidad de dinero ya no remite a la solidez del oro imaginado (Marx), sino a la virtualidad de su valor futuro en función de previsiones. Brota, por ello, una nueva forma de valorar: algo vale en función de expectativas (Castells), asumiendo que «como buena parte de lo que se intercambia a título de mercancías son transacciones monetarias futuras, lo que se comercia bajo ningún aspecto existe» ${ }^{80}$. Precisamente la nueva orientación temporal enderezada hacia lo venidero presupone que «un cálculo relativo a las expectativas de futuro es enormemente arriesgado a causa de la valoración volátil del poder del dinero, de los precios volátiles del mercado y de la demanda volátil. Este cálculo y la dependencia que demuestra la economía dineraria de las diferencias de tiempo y de los plazos vencidos, que se ha dado en llamar la "inquietud del dinero", dificulta sobremanera la orientación de la economía»81. La «inquietud del dinero» obedece, por tanto, a la incorporación de la diferencia entre presente y futuro en las operaciones económicas, expresión inmediata de que «el dinero no es sino una economía de tiempo»82.

Ésta (economía de tiempo) se ajusta a la nueva circunstancia histórica en la que el gesto austero del hombre moderno que confiaba en el ahorro como uno de los momentos clave de su enriquecimiento futuro ya no es válido. Sensible a la atmósfera posmoderna de consumo masivo, "la economía se acomoda a la idea de que ni para las empresas ni para los bancos, y hoy en día ni para las casas particulares, sea racional sufragar todos los pagos con medios ahorrados. Para esto, por supuesto, no hay límites claros, porque depende de demasiados factores imprevisibles el hecho de se puedan efectuar los pagos esperados» ${ }^{83}$. En este nuevo espacio virtual que es Internet, la inquietud del dinero se hace visi-

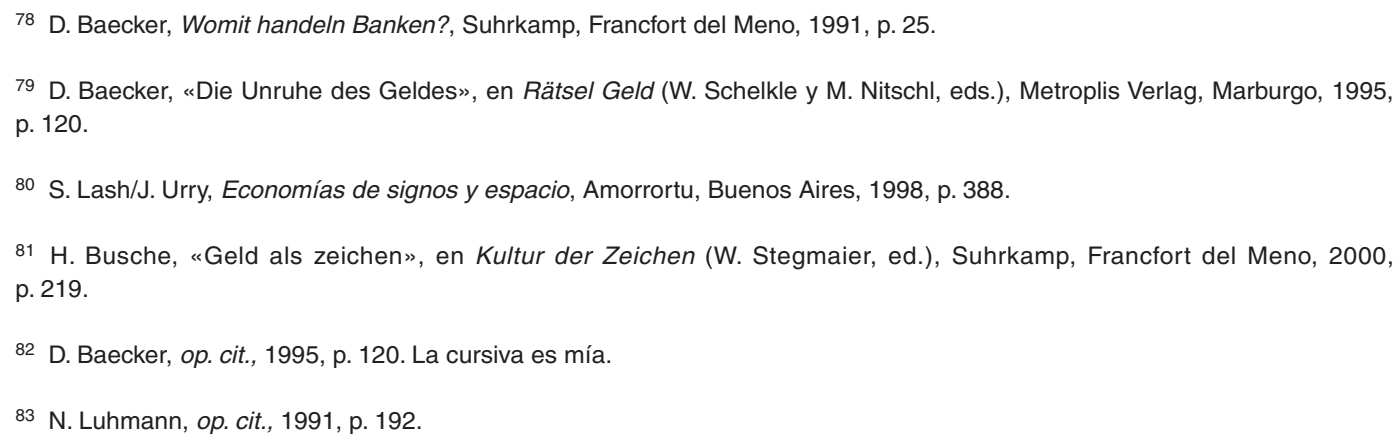


ble como riesgo, como ausencia de necesidad en el curso de las acciones de los actores sociales. Precisamente por el elevado número de agentes que intervienen, pero también por la enorme rapidez con que se transmite la información, por la inmediatez de la respuesta y por el elevado volumen de capital que se maneja, el resultado general es, según Castells, el de «un incremento exponencial de la volatilidad del mercado, ya que la complejidad, el tamaño y la velocidad provocan un modelo de comportamiento de reacción rápida en los inversores que se sirven de Internet, lo cual conduce a una dinámica caótica y a intentos de tratar de adelantarse a las expectativas del mercado, en tiempo real. Así, tanto la transformación de las finanzas como la transformación de la tecnología del comercio financiero convergen hacia una mayor volatilidad del mercado como tendencia sistémica» 84 .

Es en el momento de la reproducción de la capacidad de pago y, con ella, del dinamismo económico cuando el dinero exhibe su condición de fin en sí mismo y para símismo, cuando el dinero se piensa (reflexividad) desde el punto de vista de cómo garantizar su supervivencia. Aquí ya no prevalece su imagen de medio de cálculo, más bien predomina la de sujeto y protagonista de su propio subsistema funcional que pervive favoreciendo la marea de simulacros que inundan las avenidas y calles de nuestras cuidades como estímulos para los pagos. De suerte que «la ganancia de dinero ya no es un lujo, sino una necesidad interna de la economía; se trata de una cuestión de supervivencia»85.

Ya se ha mencionado anteriormente que la circulación del dinero conlleva que «a toda transmisión de la capacidad de pago en una dirección corresponde una transmisión de pago en otra. Quien paga se convierte en incapaz de pago al realizar su pago. Sólo se puede gastar dinero una vez" ${ }^{86}$. Se trata de subrayar la idea de que ambos momentos se necesitan para alimentar de continuo el proceso económico, que, en caso de peligro de estancamiento, hace que, en la línea de los planteamientos sistémicos de Luhmann, el subsistema económico aplique su potencial autopoiético y autorreferencial con el engranaje bancario. No en vano, «el mecanismo del crédito produce un espacio seguro con su posibilidad de generar capacidad de pago allí donde ella no resulta por sí misma en la circulación»87. De hecho, las operaciones de este mercado de dinero como diferenciación interna del subsistema económico «son altamente autorreferenciales, es decir: se orientan por la autorreferencia del sistema económico y por la reflexividad de su medio dinero»88.

\footnotetext{
84 M. Castells, La Galaxia Internet, Areté, Barcelona, 2001, p. 102.

85 H. Busche, op. cit., 2000, p. 219.

86 D. Baecker, op. cit., 1991, p. 24.

87 N. Luhmann, op. cit., 1986, p. 110.

88 N. Luhmann, op. cit., 1989, p. 110.
} 
Las aportaciones de la organización bancaria consisten en el desarrollo de un mercado financiero (es decir, de un mercado dentro del mercado) que opera como diferenciación interior del subsistema económico.

Junto a todo esto hay que añadir que en la sociedad globalizada de nuestros días el crédito se ha des-territorializado (des-nacionalizado), no es monopolio de los bancos centrales. Muy al contrario, se ha instituido un sistema de crédito separado y des-sincronizado del sistema global de producción. Este sistema de crédito global «está desregulado, se gobierna por el mercado, a diferencia de la moneda como medio de circulación, que se puede someter con más eficacia a reglas y determinaciones nacionales e internacionales. Además, este sistema de crédito global es ante todo privado. Ha crecido tanto que ha dado lugar a una sorprendente reprivatización de la economía mundial, en una escala que empequeñece a los organismos públicos que administran divisas (como el Fondo Monetario o el Banco Mundial) $>89$. Esta novedad obedece al surgimiento de redes ramificadas internacionales de bancos norteamericanos, europeos y japoneses; la formación de grupos bancarios internacionales a comienzos de la década de 1970; la fundación de consorcios bancarios internacionales al servicio de una región o de una industria en particular, etc. ${ }^{90}$.

En definitiva, la época posmoderna coincide con la aparición de «un mercado de dinero sin estado ${ }^{91}$ que consuma la necesidad del dinero de ir librándose de cualquier corsé que dificulte su circulación. En este sentido supone la victoria del dinero sobre lo político, que, como bien sabe Bauman, convierte a los Estados en meras instancias políticas favorecedoras de la implantación del capital dentro de sus fronteras. A tal fin, los Estados han de ofrecer medidas que satisfagan los intereses del dinero en materia fiscal, social y salarial. Este poder de crear crédito al margen de los controles políticos se encuentra en la base de la desterritorialización de la economía mundial. Se trata de un mercado de dinero creado por el propio dinero. En palabras de S. Lash y J. Urry, «el mercado de crédito, en particular para innovaciones financieras, y las jerarquías privadas de las empresas que producen créditos, prevalecen sobre las jerarquías públicas de regulación nacional e internacional. Se trata de nuevas formas globales de crédito que, por lo tanto, caen fuera del control de los Estados nacionales, a pesar de lo cual ejercen un poder estructural sobre cada uno de éstos ${ }^{92}$.

\footnotetext{
89 S. Lash/J. Urry, op. cit., 1998, p. 380.

90 Ibid., p. 381.

91 D. Harvey, The Condition of Postmodernity, Blackwell, Cambridge (MA), 1990, p. 162.

92 S. Lash/J. Urry, op. cit., 1998, p. 380.
} 
En esta nueva circunstancia global ya hay quien habla de la sociedad sin dinero ${ }^{93}$ o de la muerte del dinero ${ }^{94}$, porque su presencia física en la interacción social es cosa del pasado. Nuestras operaciones económicas carecen de otro interlocutor que no sea el cajero automático o el ordenador personal. El dinero se ha transustanciado ${ }^{95}$. Ya no es una cosa, algo que se pueda esconder debajo del colchón o entre las páginas de un libro. Es un sistema. Integrado en una red virtual, ha tomado forma electrónica: «no ha llegado a ser más que una conjunción de unos y ceros, las unidades fundamentales de la computación»96. Ubicuo y sin ocupar ningún espacio físico, se asemeja a «la red de neuronas del cerebro. Millones de precisos terminales de una clase u otra están interactuando en una danza electrónica sincopada, dando lugar a un ritmo de altas y bajas en el mercado no muy distinta de las pulsaciones cerebrales» 97 .

93 J. S. Coleman, Foundations of Social Theory, Cambridge (MA), 1990, p. 121.

94 J. Kurtzman, The Death of Money, Simon \& Schuster, Nueva York, 1993.

95 Ibid., p. 11.

96 Ibid., p. 16.

97 Ibid., p. 17. 